\title{
New Technique to Produce Large Amount of Flat Silk by Biospinning
}

\author{
Laura Beatriz Garay ${ }^{1}$, Andrea Nembri' ${ }^{1}$, Alana Lucia Oro ${ }^{2}$, Verônica Aureliana Fassina ${ }^{2}$, \\ Cláudia Regina das Neves Saez², Alex Sandro Chiarello², Naiara Climas Pereira², \\ Graziele Milani Pessini², Roxelle Ethienne Ferreira Munhoz ${ }^{2}$, Maria Aparecida Fernandez ${ }^{2}$ \\ ${ }^{1}$ Seda y Fibras S.R.L, Hernandarias, Paraguay \\ ${ }^{2}$ Departamento de Biotecnologia, Genética e Biologia Celular, Universidade Estadual de Maringá, Maringá, \\ Brasil \\ Email: lau_warras@hotmail.com, andrea.nembri@silkgroup.eu, alanaoro@hotmail.com, \\ fassinaveronica@gmail.com, claudiareginasaez@gmail.com, alexchiarello@hotmail.com, \\ naiaraclimas@gmail.com, grapessini@hotmail.com, roxellemunhoz@gmail.com, \\ aparecidafernandez@gmail.com
}

Received 9 October 2014; revised 27 October 2014; accepted 7 November 2014

Copyright (C) 2014 by authors and Scientific Research Publishing Inc.

This work is licensed under the Creative Commons Attribution International License (CC BY).

http://creativecommons.org/licenses/by/4.0/

(c) (7) Open Access

\begin{abstract}
Beyond the production of silk thread, there are several studies showing that the silk is a great biomaterial for surgical sutures and grafts. This paper shows a new technique to produce silk thread changing the natural cycle of silk production, which is the production of cocoons. This new method has the purpose of producing a silk fabric free of impurities, through flat surfaces. Six different surfaces were tested: Glass, Formica Surface, Steel and Zinc Sheets, Cotton tissue and Burlap Bag. The first five surfaces had not presented enough larvae alive for statistical analysis, because there were several damages in silkworms larvae that resulted in mortality and low silk production. On the other hand, the burlap bag surface presented good results for web construction by biospinning and its use was indicated for silk industry focused on biomaterials. The present study suggested the potential of naturally biospun web, using Bombyx mori, to develop a new technique to produce silk thread matrices that will have several applications at the industry and production of biomedical materials.
\end{abstract}

\section{Keywords}

Silkworm, Bombyx mori L., Silk Thread, Biomaterial

\section{Introduction}

Silk is widely known in the textile industry for their mechanical properties and brightness, produced by spiders

How to cite this paper: Garay, L.B., Nembri, A., Oro, A.L., Fassina, V.A., das Neves Saez, C.R., Chiarello, A.S., Pereira, N.C., Pessini, G.M., Munhoz, R.E.F. and Fernandez, M.A. (2014) New Technique to Produce Large Amount of Flat Silk by Biospinning. Agricultural Sciences, 5, 1483-1490. http://dx.doi.org/10.4236/as.2014.514159 
and different insect classes, they produce cocoons, eggs and traps protection [1]. Silk has been also the focus of new researches for tissue engineering and biomedicine. Bombyx mori, an insect that belongs to the Lepidoptera order, produces a silk cocoon and because of their easy handling in laboratory, it is widely used in genomic and proteomic studies, being a reference organism in biological studies [2].

Silkworm large-scale production is held by silk farmers, employed mainly by family farming, developed in small lands. This activity is the result of integration between industry and farmers that plant and cultivate mulberry (Morus sp.) that feed silkworm larvae, on the other hand, the industry promotes the breeding and production of eggs until the silkworm larvae reach the field [3]. Brazil has a favorable climate for mulberry plantation, as well as for silkworm production, thus sericulture is a good alternative crop for the country, especially for small farmers [4].

The silk thread is secreted by B. mori larvae and can measure up to 1500 meters, basically made of two fibroin proteins, which consists in a $70 \%$ to $80 \%$ hydrophobic protein, and sericin, approximately $20 \%$ to $30 \%$ hydrophilic coat protein [5]. Structurally, the silk fiber is composed of a $325 \mathrm{kDa}$ and $25 \mathrm{kDa}$ chain, which are connected by sulfide bridges, bound by a sericin chain. The silk fibroin has tripeptide glycine sequence (43\%) and alanine (30\%), which are interspersed with amino acids, such as serine or tyrosine, and they show a high complex organization [6].

Silk fibroin is a natural polymer with high potential for application as biomaterial due to its elasticity, flexibility, tensile strength, versatility, easy permeability and absorption, enzyme immobilization, substrate for cell growth, minimal inflammatory response, thermal stability, oxygenation, hemostatic property, biocompatibility and biodegradability [5] [7]-[9]. When silk thread is used in surgeries, occasional rejection has been reported and it is attributed by contamination with sericin [10]. In two years, the silk is completely absorbed and is found no trace of the same material [11].

Biomaterials devices used to repair tissue injuries has been utilized for centuries, however most of biomaterials are inadequate and can cause severe inflammatory reactions in patients. The biomaterials industry is constantly looking for materials with appropriate physical and chemical properties that cause the least possible intolerance by the body. The fibroin has several of these properties, since biomaterials of different configurations can be made, depending on requirements: gels, films, 3D porous matrices, microspheres and microfibers [12], supports adhesion of stem cells proliferation and differentiation in vitro and promoting tissue repair in vivo [10].

Biospinning is a mechanism of natural silk fibers production exploited for decades aiming to produce a silk thread better for be used in biomaterials [13]. The alternative method of non-cocoon silk utilization is the new orientation in which modern sericulture industry develops to [14].

The aim of this study was induce B. mori silkworms to spin a silk web without the formation of cocoon, creating a new technique that allows a continuous development of insect life cycle. This technique used a flat base surface, where the silkworms were placed and spinning a tissue for future potential application, which facilitated the extraction of fibroin or used the web as a biomaterial. In this study, we tested different surfaces for flat silk production.

\section{Materials and Methods}

\subsection{Cleaning Methodology}

All materials and surfaces used were cleaned and disinfected with 1\% calcium hypochlorite. The rearing house was cleaned with 3\% formalin in lime water (1 kg of hydrated lime/100 liters of water), and 1\% hypochlorite.

\subsection{Biological Material}

In this work we used commercial silkworm hybrids from Seda Y Fibras SA. The eggs were previously spraying with 3\% formalin. The hatched eggs have received a standard treatment, heated in hydrochloric acid at birth, and then 20,000 larvae were placed in each box.

\subsection{Silkworm Rearing}

During the rearing, four repetitions were performed. In all repetitions, silkworm on first and second age, were fed with chopped mulberry leaves. Larvae on third to the fifth age were fed with mulberry branches, as in the regular sericulture. Corporal disinfectant was not used on any larvae age; only hydrated lime was used in the 
base surface. The mulberry leaves were collected manually everyday to fed the larvae, chemicals herbicides or chemical fertilizers were not used in these treatments.

\subsection{Larvae}

It was important established a synchronization of silkworm larvae, to the web to be produced at the same time. For this, commercial phytoecdysteroid were used to increase productivity in sericulture, which is an ecdysteroid derived from plant source, used as a mechanism of defense. This ecdysteroid is structurally closer to the original and natural insect hormone and could be used for synchronizing the maturation activity [15] [16]. 3\% - 5\% phytoecdysteroid $\beta$-ecdysone was used for synchronization of silkworm maturation and was administered in the fifth instar at the time of initiation of spinning behavior [17]. After that, $80 \%$ of uniform mature larvae were observed in 24 hours. The larvae were separated when the first thread was spun and placed in contact with the tissue surface.

\subsection{Web Spinning}

The larvae were placed into a flat surface and the web was naturally spun, without formation of cocoon. Some tests were made with six different surfaces for conducting the web as sheet steel, zinc sheet, glass, formica, cotton tissue and burlap bag. All these webs obtained for these different techniques were analyzed. So, six different surfaces are tested for silkworm spinning.

During the spinning the web was manually cleaned, carefully to not remain any organic waste, fecal matter, mulberry leaves, dust and dead larvae between the treads. Once the larvae stopped the spinning, they were collected before the transformation to pupae, to prevent fat residues into the web. Then the tissue was cleaned with a common vacuum cleaner to remove dust and dried in stove for 3 hours at $60^{\circ} \mathrm{C}$. Finally the tissue should be free of impurities and organic waste, as well as chemical residues that could have fallen during the house cleaning or the silk gland by oral incorporation.

\section{Results and Discussion}

\subsection{Surface Analysis}

The 3\% - 5\% phytoecdysteroid $\beta$-ecdysone hormone was used and in this study promoted the larvae synchronization. Just when, $80 \%$ of uniform mature larvae were observed in 24 hours. The larvae were separated when the first thread was spun and placed in contact with the tissue surface.

Glass and Formica Surface. Formica Surface (Figure 1(A)) has a format of a tray with edges where larvae spun the cocoon. Also, as a glass surface, was observing that the larvae escaped around the edges and fell in the floor. Both materials showed low absorption and a poor contact surface for the silk fiber to be spun. These surfaces were not use in these paper results, but were consider for future research. Steel and Zinc Sheets. These surfaces (Figure 1(B)) showed some problems as the other two surfaces described previously, where larvae escaped and felt in the floor. However, these sheets did not offer adherence surface required that the larvae could walk or spun the silk thread. Both were discard and were not considered for future research. Cotton tissue. In this technique, the cotton tissue was stretched over a wood support (Figure 1(C)). Also occurred that some larvae felt into the floor, however the problem with this surface was that it had high adherence which difficult the cleaning and hygiene of the tissue, so this technique has been discarded. Burlap Bag. This material was placed over an extended breeding box (Figure 1(D)), with some inclination, which made some larvae escaped and felt in the floor, but in low quantity. The larvae had adherence which permitted 2000 larvae during 2 - 3 days spinning a tissue with $1800 \mathrm{~cm} \times 1000 \mathrm{~cm}$. This surface showed adherence, absorbent, easy cleaning, easy disinfection and it is inexpensive. The silk tissue was spun in this surface and the final product overcame the expectations. This was the surface and the final silk web chosen as the better and more advantageous for analysis corresponding production and use in the silk industry.

\subsection{Burlap Bag Tissue}

The result with burlap bag showed an average of 1370 grams of raw silk with a devoid standard (DS) 210, 1220 grams of dry web with a DS of $187 \%$ and $49.75 \%$ loss with a DS of 13.84 , that increased by 20,000 larvae in 

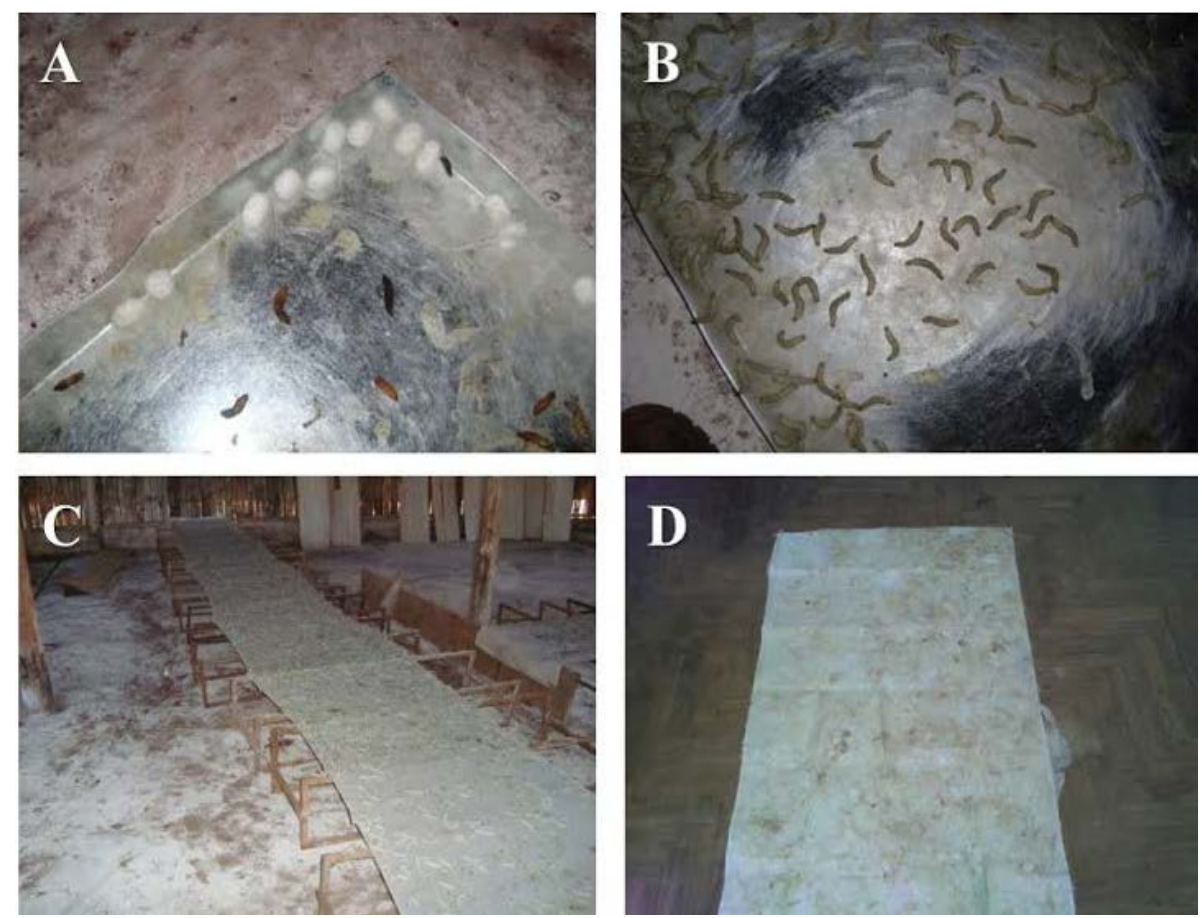

Figure 1. (A) Formica Surface. The larvae spun cocoons on the edges; (B) Steel or Zinc. Sheets surface. Non-absorbent surface which the larvae presented difficult to walk and spun silk fiber; (C) Cotton Tissue. The cotton stretched over wood; (D) Burlap Bag Surface. The final silk tissue finished on surface.

each brood box or repetition. The average production of a raw silk per larvae was 0.14 grams. The value obtained was lower than in some studies available in the literature relates to cocoon weight [18]-[22].

Bacterial infection was observed in the ending of larval cycle, even on a period that the larvae walking around and some felt into the ground. The stress caused by changing the natural cycle makes the silkworm waste more energy, together with the other symptoms descripted, the spinning cocoon until finally were weaved the tissue and the others could be lowered the immunological defenses of the silkworms becoming susceptible to diseases [23] [24]. This larval behavior can explain the loss estimated at $49.75 \%$ for disease, which was equivalent to a variation of silk released larvae. However, it is common that the larvae stop the feeding before making the cocoon, preparing for ecdysis, as a wander to locate a suitable place for cocoon formation, which causes a low stress [25] [26].

The results showed satisfactory relation of time and production of silk fiber, considering the natural spinning of this tissue, and the only addition of this technique was a phytoecdysteroid ( $\beta$-ecdysone) to ensure the same time of silk spinning and pupation. The phytoecdysteroids are a class of chemicals that plants synthesize for defense against phytophagous, such as insects. These compounds are mimics of hormones used by arthropods in the molting process known as ecdysis. In sericulture, the $\beta$-ecdysone is used to increase productivity and reported this administration at a particular time also increase cocoon weight, shell weight and shell percentage, with accepted results about uniform maturation in B. mori [15]-[17].

During the experiment, the temperature suddenly dropped below $10^{\circ} \mathrm{C}$ causing loss in the four replicates. These results agree with the temperature parameters chosen for this methodology of production that could not be less than $20^{\circ} \mathrm{C}$, because the pupae were not with the cocoon protection. This technique also allowed to the pupae complete their life cycle, after collected over the tissue, what not occurred in the usual sericulture method of cocoon production.

\subsection{Silk Production without Formation of Cocoon}

The cocoon is an intricate structure potentially serving numerous simultaneous functions, providing protection to the pupa against biodegradation and dehydration [27]. The presence of the cocoon provides the local envi- 
ronment of the pupa ensuring optimal conditions for successful pupation, besides accelerate pupal development by raising the body temperature of the developing pupae. Silk cocoons already possess anti-bacterial and anti-fungal properties [28] [29]. However, this protection occurs after the cocoon spinning and to the technique success the temperature control above $20^{\circ} \mathrm{C}$, showed significant result creating a good environment to the larvae, before and during the silk spinning.

Recent analyses of the fibers and structural properties of the cocoon showed multiple layers composed it [30]. The fibers arranged randomly in the plane of the cocoon walls, are bound by sericin to form a non-woven porous structure. This form a graded layers shows different morphologies of non-woven and in these multiple layers there are relatively weak bonds by sericin between them [31].

This heterogeneous structure consisting of two distinct types of silk fibers, large-diameter "outer" fibers, with $\sim 26 \mathrm{~nm}$ diameter, and smaller diameter inner fibers with $\sim 16 \mathrm{~nm}$ diameter, forming a tightly woven cocoon wall [32] [33]. The structure formed by silkworm cocoon can occur in this silk tissue technique without formation of cocoon, many methods use in the biomaterial industry showed mats weave randomly with silk fibers capable of similar structures founded and described in cocoon wall.

The synchronous maturation is important for large scale silk production and cocoon spinning process could be synchronized. The phytoecdysteroid do not have any effect on the properties of silk, but these administration is need based in technologies of sericiculture for physiologically manage the silkworm crop.

\subsection{Silk Tissue as a Biomaterial}

The biomaterial design is an important element of tissue engineering, this product provides a structural ways to cell attachment and must be biocompatible and elicit little to no host immune response [10] [34] [35]. Silk represent a biocompatible, degradable, mechanically superior family that offer uncountable properties [36].

A wide range of techniques support the silk biomaterial industry, some of them possess similarities with the technique showed in this paper. Eletrospinning is an attractive one, to produce fibers of the desired diameter for tissue engineering applications, but requiring instrumental set-up. Eletrospinning fibers can be produced by a method from aqueous silk fibroin solution mixed with polythyleneoxid established a fiber morphology with less than $0.8 \mathrm{~nm}$ in diameter [37]. However, this method needs high expensive equipment and chemicals solution that degree the quality of silk fiber.

Non-woven technique were prepared by native silk fibers partial solubilization, the silk fibroin mats are a biomaterial used to cell culture as a guide to cells migration, adhesion and differentiation [10] [36] [38].

This technique creates a silk fibroin mats with $10-30 \mathrm{~nm}$ in diameter and this similar thickness was found in cocoon wall [33] [34] [39].

The similar structure formed in a non-woven mats and a multilayer cocoon could be related and found in this technique for producing silk without the formation of silkworm cocoons. This fabric could have properties to attempt to replicate its characteristics in non-woven fibers used in everything from textiles to scaffolding for skin grafts.

Both of these methods can be used in the industry of silk biomaterials however its use caused damaged in the silk fiber, it has been reported that artificial silk fibers have an inferior mechanical properties compared to naturally spun silk, giving an edge to this natural method over others [40]-[44].

One of the advantages of using this silk fiber instead of cocoons is the easily extraction of fibroin and improve its use, because there were less organic residuals, such as pupae oil, remaining products of the metamorphosis, exuvia etc, that can increase the cost of the extraction. Unlike the cocoon, that contain the exuvia and raise the cost by the oil residues on it, then in this case it is necessary the chemical extraction of fibroin, using products with higher cost. This was the main reason why this studies was conducted, in other words, to reduce the cost of fibroin extraction and increase the amount of fibroin extracted.

The evaluation of silk quality is based on the raw silk percent, which is the amount of silk produced after unwinding the cocoon, the wire length can also be evaluated, among other characteristics. In the present study these characteristics were not evaluated due the fact that the cocoon material is not intentioned to be spinning, thus this analysis will not be relevant in this work. In future studies there is the intention to evaluate protocols that prove the easily fibroin extraction in this silk fiber, comparing to the silk from the cocoon and the silk yarn, also the amount of fibroin obtained is this different protocols. In this work we aimed to produce a new technic aimed the silk production focused on the extraction of a pure and clean fibroin, therefore its higher production. 


\subsection{Biospinning}

Another new technique related was observed in the wild Saturniid silkworm Antheraea mylitta denominated "biospinning” [13]. This was the only technique present in the literature, until now, using a natural method to biofabricate a silk fiber matrices that can be used for future applications as a biomaterial. This method consists in A. mylitta larvae spinning fibers and fabricating matrices with linear or mixed orientations on coverslip surfaces measuring $20 \times 25 \mathrm{~mm}$. In the randomly aligned only one silkworm were placed on Teflon-coated glass plates and spun layer by layer on it, while in the technique of $B$. mori silk tissue, many larvae produced a largest tissue in a cheaper surface.

The silk tissue of B. mori also could be denominated biospinnig and showed some advantages, B. mori has higher economic importance, has a consolidated rearing, the mulberry silk is the most studied, searched and used in the world. The present technique has suggested the potential of naturally biospun tissue, by mulberry silkworm B. mori, for develop a new technique for production of silk fibrous matrices and various industry and biomedical applications in the future. It is worth emphasizing that methodology can be applied commercially on a large-scale.

\section{Conclusion}

This new technique demonstrated a new perspective to the sericulture based in producing a silk web without formation of silkworm cocoon. This method, produced a new and alternative route using silk fibers directly from silkworms, woven the tissue, with natural spinning process without any chemical processing, or impurities, or interrupt the life cycle of the insect, could be used in the textile industry and biomaterial engineering application. In accordance with the results obtained, it was found that the five surfaces (Glass and Formica Surface, Steel and Zinc Sheets and Cotton tissue) did not show larvae alive in sufficient number for statistical analysis. Therefore, these treatments have inflicted severe damages in the silkworm larvae and resulting in mortality and low silk production. On the other hand, the burlap bag surface presented good results for web construction by biospinning and its use was indicated for silk industry focused on biomaterials.

\section{Acknowledgements}

This work was supported by CAPES, CNPq, FINEP/Fundação Araucária and Secretaria de Estado da Ciência, Tecnologia e Ensino Superior-FUNDO PARANÁ.

\section{References}

[1] Kaplan, D.L., Mello, S.M., Arcidiacono, S. and Fossey, S. (1998) Senecal KWM. Materiais à base de proteínas, McGrath KKD, Boston.

[2] Zhong, W.Y., Hogan, R.J. and Haigh, J.D. (2008) Three-Dimensional Radiative Transfer in Midlatitude Cirrus Clouds. Royal Meteorological Society, 134, 199-215. http://dx.doi.org/10.1002/qi.182

[3] Conab-Companhia Nacional de Abastecimento. Casulo de seda proposta de preço mínimo safra 2006/2007. www.conab.gov.br/OlalaCMS/uploads/arquivos/a4b04fbccd091af741fc36f2965ca85e.pdf

[4] Fernandez, M.A., Ciferri, R.R., Patussi, E.V., Pereira, M.F., Felipes, J., Bravo, J.P., Zanatta, D.B., Gouveia, F.S. and Balani, V.A. (2005) Utilização da biotecnologia na sericicultura brasileira. Biotecnologia Ciência e Desenvolvimento, 35, 56-61.

[5] Kong, X.D., Wang, X.M. and Cui, F.Z. (2005) Preparation of Hydroxyapatite-Fibroin Nanocomposites. Engineering Materials, 228-289, 191-194.

[6] Mondal, K. and Trived, S. (2007) The Silk Proteins, Sericin and Fibroin in Silkworm, Bombyx mori. Caspian Journal of Environmental Sciences, 5, 63-76.

[7] Kundu, B. and Kundu, S.C. (2010) Osteogenesis of Human Stem Cells in Silk Biomaterial for Regenerative Therapy. Progress in Polymer Science, 35, 1116-1127.

[8] Hardy, J.O., Lin, M.R. and Scheilbel, T. (2008) Polymeric Materials Based on Silk Proteins. Polymer, 46, $4309-4327$.

[9] Gu, Z.W., Han, Y.F., Pan, F.S., Wang, X.T., Weng, D. and Zhou, S.X. (2009) Preparation and Characteristics of Gradient Silk Fibroin-Hydroxyapatite. Porous Composites Materials Science Forum, 610-613, 1231-1236.

[10] Wang, Y., Kim, H.J., Vunjak-Novakovic, G. and Kaplan, D.L. (2006) Stem Cell-Based Tissue Engineering with Silk Biomaterials. Biomaterials, 36, 6064-6082. http://dx.doi.org/10.1016/j.biomaterials.2006.07.008 
[11] Altman, G., Diaz, F., Jakuba, C., Calabro, T., Horan, R.L., Chen, J., Lu, H., Richmond, J. and Kaplan, D.L. (2003) Silk-Based Biomaterials. Biomaterials, 4, 401-416. http://dx.doi.org/10.1016/S0142-9612(02)00353-8

[12] Sofia, S., McCarthy, M.B., Gronowicz, G. and Kaplan, D.L. (2001). Functionalized Silk-Based Biomaterials for Bone Formation. Journal of Biomedical Materials Research, 54, 139-148. http://dx.doi.org/10.1002/1097-4636(200101)54:1<139::AID-JBM17>3.0.CO;2-7

[13] Mandal, B.B. and Kundu, S.C. (2010) Biospinning by Silkworms: Silk Fiber Matrices for Tissue Engineering Applications. Acta Biomaterialia, 6, 360-371. http://dx.doi.org/10.1016/j.actbio.2009.08.035

[14] Wang, D.G. (2009) Judgment and Analysis on the Success \& Failure of Modern Sericicultural Industry Development. Asian Agricultural Research, 1, 13-52.

[15] Chou, W.S. and Lu, H.S. (1980) Growth Regulation and Silk Production in Bombyx mori L. from Phytogenous Ecdysteroids. In: Hoffman, J.A., Ed., Progress in Ecdysone Research, Elsevier/North Holland Biomedical Press, Amesterdam.

[16] Zhuang, D.H., Xiang, M. and Gui, Z.Z. (1992) The Practical Studies on the Growth and Development by Insect Hormones in the Silkworm Bombyx mori. The 19th International Congress Entomology, Beijing.

[17] Zia, H.R., Munshi, N.A., Sharma, R. K., Ganie, N.A. and Malik, G.N. (2012) Effect of Phytoecdysteroid ( $\beta$-Ecdysone) on Synchronization of Maturation in Silkworm Bombyx mori L. International Journal of Advanced Biological Research, 2, 238-240.

[18] Porto, A.J. and Okamoto, F. (2003) Desempenho Produtivo de Quatro Raças do Bicho-da-Seda (Bombyx mori L.) e Seus Cruzamentos. Boletim de Indústria Animal, 60, 179-184.

[19] Porto, A.J., Okamoto, F., Cunha, E.A. and Otsuk, I.P. (2004) Caracterização de oito Raças do Bicho-da-Seda (Bombyx mori L.). Ciência Rural, 34, 259-264. http://dx.doi.org/10.1590/S0103-84782004000100040

[20] Rao, C.G., Seshagiri, S.V., Ramesh, C., Ibrahim, B.K., Nagaraju, H. and Chandrashekaraia (2006) Evaluation of Genetic Potential of the Polyvoltine Silkworm (Bombyx mori L.) Germplasm and Identifi Cation of Parents for Breeding Programme. Journal of Zhejiang University Science B, 7, 215-220. http://dx.doi.org/10.1631/jzus.2006.B0215

[21] Zanatta, D.B., Bravo, J.P., Barbosa, J.F., Munhoz, R.E.F. and Fernandez, M.A. (2009) Evaluation of Economically Important Traits from Sixteen Parental Strains of the Silkworm Bombyx mori L (Lepidoptera: Bombycidae). Neotropical Entomology, 38, 327-331. http://dx.doi.org/10.1590/S1519-566X2009000300005

[22] Najafil, N., Seidavi, A.R., Mirhosseini, S.Z., Gharahveysil, S., Mavvajpour, M. and Salehi, N. (2011) Analysis of Genetic Divergence for Classification and Evaluation of 37 Productive Performances in 54 Oval Cocoon Strains of Iran Silkworm Germplasm. African Journal of Biotechnology, 82, 19218-19243.

[23] Sengupta, K., Kumar, P. and Baig, M. (1990) Govindaiah Handbook on Pest and Disease Control of Mulberry and Silkworm. UNESCAP United Nations Economic and Social Commission for Asia and the Pacific, Bangkok.

[24] Chapman, R.F. (1998) The Insect Structure and Function. American Elsevier Publishing Company, New York, 533566.

[25] Fonseca, A.S. and Fonseca, T.C. (1986) Cultura da Amoreira e Criação do Bicho-da-Seda. São Paulo.

[26] Asakura, T., Umemura, K., Nakazawa, Y., Hirose, H., Higham, J. and Knight, D. (2007) Some Observations on the Structure and Function of the Spinning Apparatus in the Silkworm Bombyx mori. Biomacromolecules, 8, 175-181. http://dx.doi.org/10.1021/bm060874z

[27] Gauthier, N., Mandon, N., Renault, S. and Bénédet, F. (2004) The Acrolepiopsis assectella Silk Cocoon: Kairomonal Function and Chemical Characterization. Journal of Insect Physiology, 50, 1065-1074. http://dx.doi.org/10.1016/j.jinsphys.2004.09.008

[28] Lyon, B.E. and Cartar, R.V. (1996) Functional Significance of the Cocoon in Two Arctic Gynaephora Moth Species. Proceedings of the Royal Society B Biological Sciences, 263, 1159-1163. http://dx.doi.org/10.1098/rspb.1996.0169

[29] Fedic, R., Zurovec, M. and Sehnal, F. (2002) The Silk of Lepidoptera. Journal of Insect Biotechnology and Sericology, 71, 1-15.

[30] Zhao, H.P., Feng, X.Q., Cui, W.Z. and Zou, F.Z. (2007) Mechanical Properties of Silkworm Cocoon Pelades. Engineering Fracture Mechanics, 74, 1953-1962. http://dx.doi.org/10.1016/j.engfracmech.2006.06.010

[31] Chen, F.J., Porter, D. and Vollrath, F. (2012) Silk Cocoon (Bombyx mori): Multi-Layer Structure and Mechanical Properties. Acta Biomaterialia, 8, 2620-2627. http://dx.doi.org/10.1016/j.actbio.2012.03.043

[32] Zhao, H.P., Feng, X.Q., Yu, S.W., Cui, W.Z. and Zou, F.Z. (2005) Mechanical Properties of Silkworm Cocoons. Polymer, 46, 9192-9201. http://dx.doi.org/10.1016/j.polymer.2005.07.004

[33] Blossman-Myer, B. and Burggren, W.W. (2010) The Silk Cocoon of the Silkworm, Bombyx mori: Macro Structure and Its Influence on Transmural Diffusion of Oxygen and Water Vapor. Comparative Biochemistry and Physiology, Part A, 155, 259-263. 
[34] Unger, R.E., Wolf, M., Peters, K., Motta, A., Migliaresi, C. and Kirkpatrick, J.C. (2004) Growth of Human Cells on a Non-Woven Silk Fibroin Net: A Potential for Use in Tissue Engineering. Biomaterials, 25, 1069-1075. http://dx.doi.org/10.1016/S0142-9612(03)00619-7

[35] Wang, Y.Z., Blasioli, D.J., Kim, H.J., Kim, H.S. and Kaplan, D.L. (2006) Cartilage Tissue Engineering with Silk Scaffolds and Human Articular Chondrocytes. Biomaterials, 27, 4434-4442. http://dx.doi.org/10.1016/j.biomaterials.2006.03.050

[36] Vepari, C. and Kaplan, D.L. (2007) Silk as a Biomaterial. Progress in Polymer Science, 32, 991-1007. http://dx.doi.org/10.1016/j.progpolymsci.2007.05.013

[37] Jin, H.J., Fridrikh, S.V., Rutledge, G.C. and Kaplan, D.L. (2002) Electrospinning B. mori Silk with Poly (Ethylene Oxide). Biomacromolecules, 6, 1233-1239. http://dx.doi.org/10.1021/bm025581u

[38] Armato, U., Dal Para, I., Kesenci, K., Migliaresi, C. and Motta, A. (2002) Method for the Preparation of Non-Woven Silk Fibroin Fabrics. Patent, PTC WO 02/29141 A1.

[39] Unger, R.E., Peters, K., Wolf, M., Motta, A., Migliaresi, C. and Kirkpatrick, C.J. (2004) Endothelialization of a Nonwoven Silk Fibroin Net for Use in Tissue Engineering: Growth and Gene Regulation of Human Endotelial Cells. Biomaterials, 25, 5137-5146. http://dx.doi.org/10.1016/j.biomaterials.2003.12.040

[40] Liivak, O., Blye, A., Shah, N. and Jelinski, L.W. (1998) A Microfabricated Wet-Spinning Apparatus to Spin Fibers of Silk Proteins. Structure-Property Correlations. Macromolecules, 31, 2947-2951. http://dx.doi.org/10.1021/ma9716261

[41] Seidel, A., Liivak, O., Calve, S., Adaska, J., Ji, G.D., Yang, Z.T., Grubb, D., Zax, D.B. and Lynn, W. J. (2000) Regenerated Spider Silk: Processing, Properties, and Structure. Macromolecules, 33, 775-780. http://dx.doi.org/10.1021/ma990893j

[42] Shao, Z.Z., Vollrath, F., Yang, Y. and Thgersen, H.C. (2003) Structure and Behaviour of Regenerated Spider Silk. Macromolecules, 36, 1157-1161. http://dx.doi.org/10.1021/ma0214660

[43] Jiang, P., Liu, H.F., Wang, C.H., Wu, L., Huang, J.Z. and Guo, C. (2006) Tensile Behavior and Morphology of Differently Degummed Silkworm (Bombyx mori) Cocoon Silk Fibres. Materials Letters, 60, 919-925. http://dx.doi.org/10.1016/j.matlet.2005.10.056

[44] Holland, C., Terry, A.E., Porter, D. and Vollrath, F. (2007) Natural and Unnatural Silks. Polymer, 48, 3388-3392. http://dx.doi.org/10.1016/j.polymer.2007.04.019 
Scientific Research Publishing (SCIRP) is one of the largest Open Access journal publishers. It is currently publishing more than 200 open access, online, peer-reviewed journals covering a wide range of academic disciplines. SCIRP serves the worldwide academic communities and contributes to the progress and application of science with its publication.

Other selected journals from SCIRP are listed as below. Submit your manuscript to us via either submit@scirp.org or Online Submission Portal.
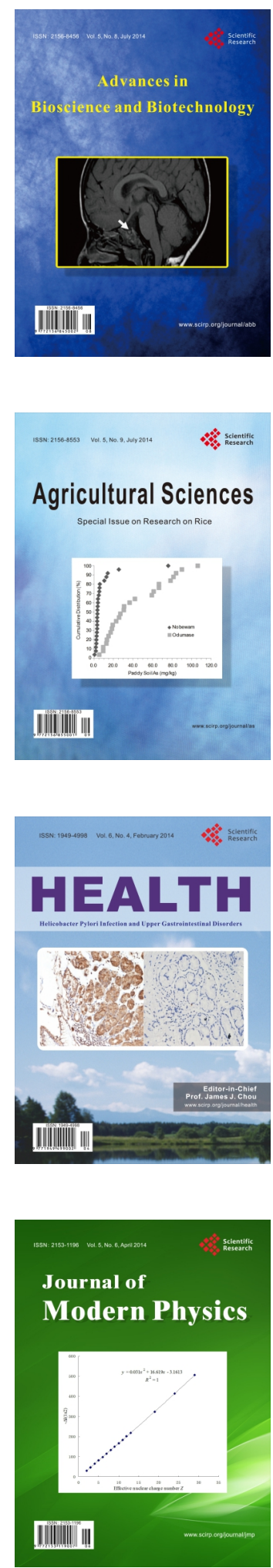
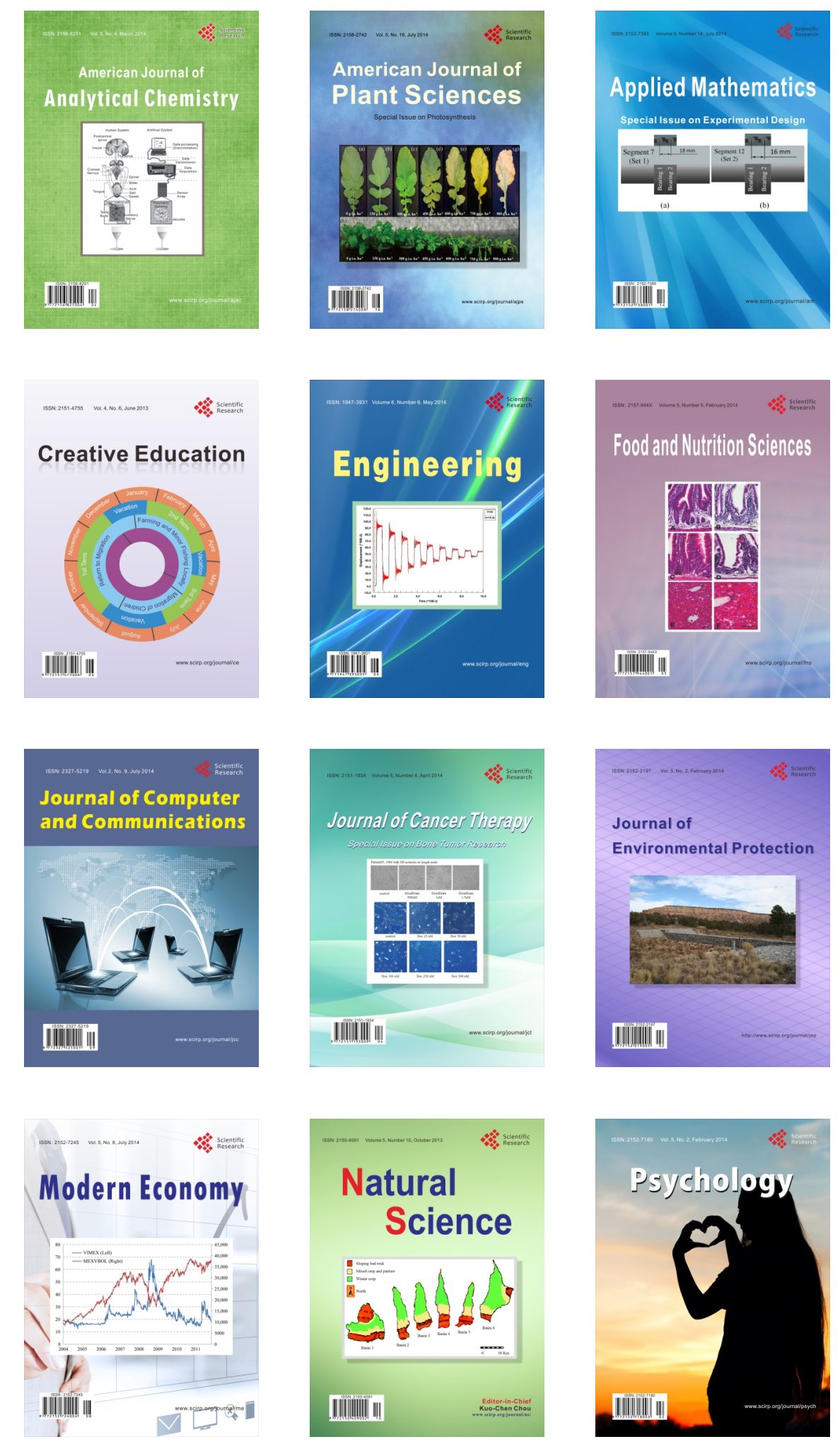